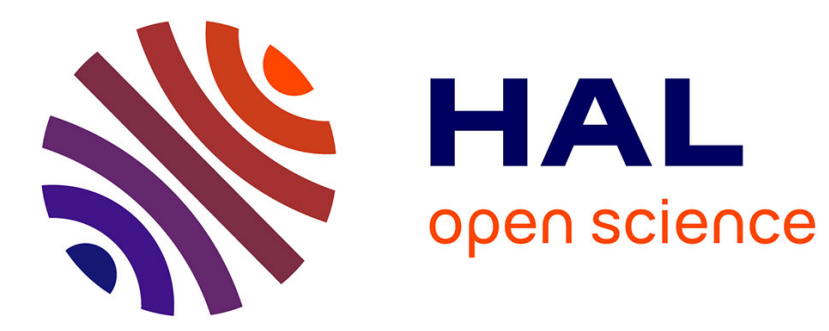

\title{
Primary Exposure and Effects in Non-target Animals
}

Richard Shore, Michael Coeurdassier

\section{To cite this version:}

Richard Shore, Michael Coeurdassier. Primary Exposure and Effects in Non-target Animals. Anticoagulant rodenticides and wildlife, pp.135-157, 2018, 10.1007/978-3-319-64377-9_6 . hal-02539410

\section{HAL Id: hal-02539410 https://hal.science/hal-02539410}

Submitted on 5 Jan 2022

HAL is a multi-disciplinary open access archive for the deposit and dissemination of scientific research documents, whether they are published or not. The documents may come from teaching and research institutions in France or abroad, or from public or private research centers.
L'archive ouverte pluridisciplinaire HAL, est destinée au dépôt et à la diffusion de documents scientifiques de niveau recherche, publiés ou non, émanant des établissements d'enseignement et de recherche français ou étrangers, des laboratoires publics ou privés. 


\section{Chapter 6}

\section{Primary exposure and effects in non-target animals}

Shore, R.F. ${ }^{1}$ and Coeurdassier M. ${ }^{2}$

${ }^{1}$ Centre for Ecology \& Hydrology, Lancaster Environment Centre, Library Avenue, Bailrigg, Lancaster LA1 4AP, UK.

Phone: ++ 44 (0)1524 595867

E-mail: rfs@ceh.ac.uk

${ }^{2}$ Laboratoire Chrono-environment, UMR 6249 CNRS/Université Bourgogne Franche-Comté, 16 route de Gray, F-25030 Besançon cedex, FRANCE

Phone: +33 (0)381 665741

E-mail: michael.coeurdassier@univ-fcomte.fr 


\begin{abstract}
The toxicity of anticoagulant rodenticides to non-target species is one of the root concerns over wide-scale use of these compounds. Compared with the numerous studies documenting secondary exposure in predators, there have been relatively few studies on primary exposure in non-targets. We consider why primary exposure of non-targets occurs, which species are most likely to be exposed, how and why exposure magnitude varies, and whether exposure results in ecologically significant effects. Species groups or trophic guilds most at risk of primary exposure include invertebrates, reptiles, birds and mammals. Relatively little is known about exposure and particularly effects in invertebrates and reptiles although recent studies suggest that anticoagulants may impact invertebrates, presumably through different toxic pathways to those that result in vertebrate toxicity. Amongst higher vertebrates, primary exposure occurs in some bird species but there is little information on extent and importance. There are more studies on non-target mammals and it is granivorous species that are most likely to feed on bait and accumulate residues, as might be predicted given their ecological and trophic similarities to target species. However, studies suggest a surprisingly high degree of exposure in shrews, although it is unclear the extent to which this is primary and/or secondary. Overall, arguably the most striking aspect of primary exposure in mammals is the large-scale variation both in the proportion of animals exposed and the magnitude of residues accumulated. We consider the multiple abiotic and biotic factors that may drive this, including the direct and indirect effects of resistance in target species. In terms of ecologically significant effects, primary exposure clearly does cause acute mortalities in nontarget vertebrates and these have been associated with significant population impacts on intensively baited islands where there has been limited or no potential for immigration. Localised population impacts have also been documented in mainland small mammals but most non-targets are likely to be r-selected species. Population declines may therefore be expected to be relatively short-term, provided baiting is episodic, as population numbers can recover through high intrinsic rate of reproduction in survivors, reduced density-dependent mortality, and immigration. However, prolonged or permanent baiting may potentially result in long-term depletion of resident non-target populations that is ameliorated only by immigration; such areas may act as population sinks.
\end{abstract}

\title{
Keywords
}

Primary exposure, non-targets, invertebrates, reptile, bird, small mammal, granivores, resistance, population effects 


\section{Contents}

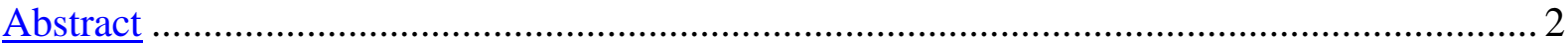

Keywords

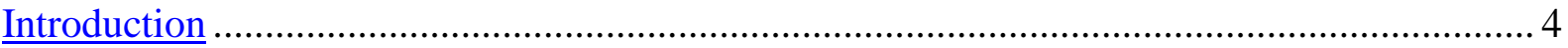

Why and how does primary exposure of non-targets occur? .................................................... 5

Which not-target species are likely to be exposed? ................................................................ 6

Magnitude of residues in non-target species resulting from primary exposure ….................... 8

Causes of variation in anticoagulant rodenticide residues in non-target small mammals ....... 14

$\underline{\text { Resistance and implications for primary exposure of non-target species } . . . . . . . . . . . . . . . . . . . . . . . . . . . . . ~} 17$

Evidence of ecologically significant effects in non-target species from primary exposure..... 18

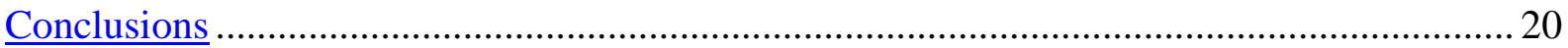

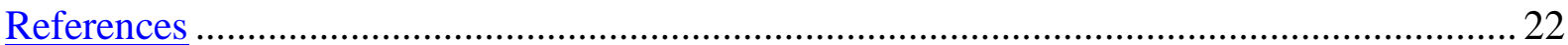




\section{Introduction}

There are a number of reasons mooted as to why there is a need to control rodent populations. These include preventing the transmission of diseases that impact humans and livestock, curtailing the consumption and spoilage of crops, foodstuffs and forestry, and reducing damage to infrastructure (Meyer and Kaukeinen 2015; Lund 2015). Anticoagulant rodenticides (ARs) are a key means of controlling rodent populations and are used throughout the world. Indeed, it is argued they are the only effective means currently available by which established rodent infestations and plagues can be controlled or eradicated (Chapter 2; Rattner et al. 2014). However, the toxic mode of action of ARs is such they inactivate vitamin K epoxide reductase, thereby disrupting the carboxylation of clotting factors and, subsequently, the clotting cascade (Rattner et al. 2014). It has long been recognised that the blood clotting mechanism is highly conserved in vertebrates and follows the same fundamental pattern (Doolittle and Feng 1987) and so ARs are potentially toxic to all vertebrates, not just rodent pest species.

It is this potential toxicity to so called "non-targets" - species not the subject of control measures - that is one of the root causes of concern over wide scale use of ARs. However, the concept of non-target species is somewhat context-specific, at least when considering primary exposure (exposure through direct feeding on AR bait). Three commensal species , the black or ship rat (Rattus rattus), the Norway or brown rat (Rattus norvegicus) and the house mouse (Mus domesticus) are disproportionally important as pests because of their severe, generalist and geographically widespread impacts (Capizzi et al. 2014). They are typically considered to be target species. There are also a wide range of other rodent species that are subject to AR control at various times in particular areas and regions. Usually, this is because of the damage they do to agricultural crops, commercial grassland and forestry. Such species include the water vole (Arvicola scherman formerly Arvicola terrestris) in grasslands in Europe (Coeurdassier et al. 2012; Saucy et al. 2001), Microtus voles, mice (Apodemus, Peromyscus) and ground squirrels (Citellus, Spermophilus) in Eurasia and North America (Witmer et al. 2014; Luque-Larena et al. 2013; Merson et al. 1984; Jokic et al. 2012; Moran 2001; Sterner et al. 1998; Wood and Singleton 2015), pikas (Ochotona spp) and the plateau zorkor (Myospalax baileyi) in upland areas of China (Wood and Singleton 2015), and pocket gophers (Thomomys bottae) and prairie dogs (Cynomys spp) in North America (Baldwin et al. 2014; Ruder et al. 2011; Salmon and Dochtermann 2006). Some of these species enjoy legal protection in regions and countries where they are not controlled and, if not the specific subject of a control programme, would generally be considered to be non-targets.

To date, a major focus of concern regarding exposure and effects of ARs in wildlife, especially the second generation anticoagulant rodenticides (SGARs), has been on predatory birds and mammals. Exposure in these species is thought to be secondary (exposure through consumption of prey that fed on bait or on other exposed animals - Chapter 7; Shore et al. 2015). In comparison, there have been far fewer studies on primary exposure (direct ingestion of bait containing active substance) in non-target species, except perhaps in countries such as New Zealand where there have been very extensive baiting programmes (Spurr et al. 2005; Hoare and Hare 2006; Eason and Spurr 1995). In this chapter, we focus on primary exposure in non-target species, albeit with the caveat that categorising species as primarily or 
secondarily exposed is a somewhat artificial concept. Exposure in many non-targets is likely to involve both primary and secondary routes rather than a single pathway. This is because species can be relatively plastic and opportunistic in their feeding habits. For example, direct ingestion of bait is thought to be the chief exposure route in the mainly granivorous wood mice (Apodemus sylvaticus) (Brakes and Smith 2005; Townsend et al. 1995) but this species will feed on invertebrates (Harris and Yalden 2008) and granivorous species will also scavenge (Howald et al. 1999), both potentially resulting in secondary exposure to ARs. Conversely, many shrew species feed predominantly on invertebrates but they will take grainbased AR baits (Brakes and Smith 2005; Townsend et al. 1995; Ericsson and Urban 2004); they may also directly ingest bait particles in soil when capturing invertebrate prey.

Overall, our aims in this chapter are to consider exposure to and the effects of ARs in nontarget species in which direct feeding on bait is the likely predominant exposure pathway. We consider why such exposure occurs and which non-target species are most likely to be exposed, how and why exposure magnitude varies, and whether exposure results in ecologically significant effects. Although primary exposure can be involved in incidents of illegal deliberate poisoning of wildlife, we do not include consideration of such exposure scenarios here.

\section{Why and how does primary exposure of non-targets occur?}

Ideally, AR baits would only be accessible or palatable to target species during control operations. This would prevent primary exposure of non-target species. The success to which this can be achieved may vary with the types of bait formulation, with the locations where bait is deployed and with the degree of bait protection.

With regards bait formulation, the most overriding difficulty perhaps is that most rodent pests are omnivorous. If baits are to be palatable and efficacious to target species, then they are also likely to be attractive to most non-target rodents and potentially to other non-target species. A variety of AR bait formulations are available (Buckle and Eason 2015) and these vary in their palatability for target species, and likely for non-targets too. Although relatively unpalatable baits may reduce non-target uptake, they are often less likely to be efficacious for controlling target species. We are not aware of clear examples where baits have been designed successfully such that they are palatable only to target rodents.

The locations where AR baits are deployed may also affect non-target exposure. In some countries, restriction of the use of ARs to within buildings has been applied to some ARs, particularly the most potent SGARs. Indoor-only use can be effective in controlling mouse infestations within buildings and curtails exposure of non-target species which rarely or only occasionally enter buildings. However, rat control cannot be achieved through solely indoor use of AR because rats do not typically nest indoors. Furthermore, use of ARs to protect croplands, grassland and forestry also self-evidently requires open area use of rodenticides. When used outdoors, baits can be placed down the burrow entrance of the target species (Tobin et al. 1997; Khan et al. 1998) or specifically inserted into tunnel/gallery systems (Jacquot et al. 2013; Sage et al. 2008). This may to some extent reduce but not eliminate non- 
target exposure but efficacy of control of target species will in part depend on ability to locate a high proportion of occupied burrows.

Depending on the nature of the control programme, baits can be protected when placed outside. The aim is to prevent non-target species, including people, from accessing and eating baits. Simple protection measures can involve placing baits under slates or other simple coverings. More substantial protection includes the deployment of bait boxes into which the bait is placed (Towns and Broome 2003). Bait can sometimes be dragged out from boxes into more open areas (Howald et al. 1999; Pryde et al. 2013) where it may be readily accessible to a range of species. Tamper -resistant bait stations are designed to prevent such manipulation and have been recommended for outdoor control of brown rats in Europe (Berny et al. 2014), although securing bait in boxes may result in less effective bait take control (Buckle and Eason 2015). Bait protection and bait boxes can reduce the exposure of larger non-target mammals and birds but non-targets that are of similar or smaller size to the target species will still be able to enter and feed from protected bait stations and boxes. Direct observational studies have shown that non-targets do enter bait stations and so access bait (Pryde et al. 2013; Eason and Spurr 1995; Elliott et al. 2014; - see also https://www.youtube.com/watch?v=nWCvbdBCTd4)

\section{Which not-target species are likely to be exposed?}

There are a number of distinct groups or trophic guilds of non-target species that are most likely to be subject to primary exposure. Perhaps the least well characterised are reptiles and invertebrates. Exposure in reptiles has attracted relatively little study. While there is growing evidence that they will feed directly on baits (Hoare and Hare 2006; Pitt et al. 2015; SanchezBarbudo et al. 2012) and be at risk of poisoning, there is little quantitative information on the scale of exposure and effects. There are a greater number of studies which have documented primary exposure in terrestrial invertebrates and they are known to feed directly on baits (Bowie and Ross 2006; Elliott et al. 2014; Ogilvie et al. 1997; Spurr and Drew 1999; Eason and Spurr 1995). The importance of this trophic transfer pathway is reflected by the occurrence of secondary exposure in predominantly or exclusively insectivorous species (Dennis and Gartrell 2015; Dowding et al. 2010; Lopez-Perea et al. 2015). Perhaps surprisingly, primary exposure of invertebrates also occurs in marine systems. This has been associated with use of ARs when eradicating rodents from islands, typically those with important seabird colonies (Howald et al. 2015). AR baits are palatable to and can be taken by species such as crabs and may also be transported through run-off into coastal waters where fragments are ingested by various marine species (Masuda et al. 2015; Pain et al. 2000; Pitt et al. 2015).

In terms of higher vertebrates, the species that are most likely to feed directly on bait are granivores, herbivores and omnivores (Sanchez-Barbudo et al. 2012), particularly those that compete with target species for food resources (Smith and Shore 2015). Various non-target mammal and bird species have been shown to feed directly on ARs (Berny et al. 2010b; Brakes and Smith 2005; Elliott et al. 2014; Geduhn et al. 2014; Masuda et al. 2014; Pryde et 
al. 2013; Ruder et al. 2011; Tosh et al. 2012; Wood and Phillipson 1977; Ericsson and Urban 2004). Often however, exposure events are not directly observed and the exposure pathway can only be inferred from known dietary preferences. It is likely though that the detection of AR residues in ruminants and other domestic grazers, and in wildlife such as hares, rabbits, deer, doves and gamebirds for example (Berny et al. 2005; Berny et al. 2010b; Ericsson and Urban 2004; Sanchez-Barbudo et al. 2012), is a result of primary exposure. This pathway may also be significant in predatory and scavenging species that are not obligate carnivores and are relatively omnivorous; such species include foxes, badgers and raccoons and a variety of birds. However, distinguishing whether exposure in such species is predominantly primary or secondary is difficult and requires detailed studies of the feeding behaviour of individuals.

Monitoring schemes that investigate non-target exposure of vertebrates to ARs typically focus mostly on predatory species (for example see Walker et al. 2008) in which exposure is most likely to be secondary. Although there are post-registration mortality incident monitoring schemes, the wildlife examined by such schemes for ARs also largely tend to be predators that are exposed secondarily. For example, in the UK's Wildlife Incident Investigation Scheme (WIIS) (Brown et al. 1996; Hardy et al. 1986), less than 7\% of the 933 incidents reported from 2012 through 2014 involved non-target species likely to have fed directly on baits (http://www.pesticides.gov.uk/guidance/industries/pesticides/topics/reducingenvironmental-impact/wildlife/WIIS-Quarterly-Reports.htm). Generically therefore, there is a paucity of quantitative data about which non-target species are primarily exposed to ARs. However, data from France's SAGIR network (Berny et al. 2010a) indicated that, in 836 incidents reported, wild boar (Sus scrofa) (19\%) and brown hare (Lepus europaeus) in roughly equal numbers made up almost $40 \%$ of the animals found dead after water vole control operations between 1998-2013 in Franche-Comté and Auvergne (Berny et al. 2005; Berny et al. 2010b; Ericsson and Urban 2004; Sanchez-Barbudo et al. 2012). Both species, and particularly hares, are likely to be exposed through eating bait, and these data indicate that primary poisoning of non-targets can be substantial.

There have been a small number of studies in which primary exposure of non-target small mammals has been specifically investigated. These provide some indication of how the likelihood of exposure varies within this species guild. We examined 12 such studies (Table 1). Eight involved controlled applications of SGARs in bait stations in or around farms and all included analysis of residues in non-target rodent species; three reported exposure in shrews. The limited number of studies does not warrant a quantitative meta-analysis to identify the main factors controlling exposure of non-target small mammals but some consistencies between the studies are apparent. Target species were usually the most exposed organisms but non-target small mammals were widely exposed to ARs in most studies. Only Elliott et al. (2014) reported a very low occurrence of ARs in non-target small mammals generally, with less than $5 \%$ of individuals exposed. In the other studies, the frequency of detection of AR residues was generally greater but differed between species. Apodemus spp. (mainly the wood mouse) and the bank vole (Myodes glareolus) were the most exposed non-target small mammal species with median \% occurrence of residues of $18 \%$ (min-max: 6-57\%) and 15\% (3-31\%) respectively (Table 1). Compared with wood mice and bank voles, fewer non-target Microtus voles were exposed when ARs were used as biocides (median: 7\%; range 3-19.5\%), although common voles were widely exposed (36- $41 \%$ of individuals contaminated) when ARs were used as plant protection products against the sympatric water vole (Jacquot et al. 
2013; Sage et al. 2008). Shrews were also frequently exposed to ARs in the studies we examined. In the studies conducted in Europe, the highest occurrence of AR residues (66\%) was reported for the great white-toothed shrew (Crocidura russula) (Geduhn et al. 2014). Sorex spp. were also commonly exposed in studies, with $28-30 \%$ of individuals contaminated (Geduhn et al. 2014; Townsend et al. 1995).

Overall, it is the more granivorous amongst the non-target rodent species that appear to be the most widely exposed to ARs. This is as might be predicted given their ecological and trophic similarities to target species. The apparently relatively high scale of exposure in shrews is perhaps more surprising, although data are limited. The potential importance of exposure of insectivores to ARs has been highlighted previously (Dowding et al. 2010) but what is unclear is the extent to which such exposure may be primary or is secondary [through consumption of contaminated invertebrates]. The impact of AR exposure in insectivorous mammals deserves further attention.

The exposure patterns in non-target small mammals are to some extent reflected in the studies which have observed primary exposure in birds, with reports of passerines such as the house sparrow (Passer domesticus) and South island robin (Petroica australis) feeding directly on baits (Elliott et al. 2014; Pryde et al. 2013); insectivorous birds may also be exposed through contamination of contaminated invertebrates. We are not aware of any systematic studies in which quantitative analysis of the extent of primary exposure in birds has been attempted. Most reports have been casual observations.

\section{Magnitude of residues in non-target species resulting from primary exposure}

A small number of the studies highlighted in Table 1 also reported the AR residue accumulated in the livers of non-target small mammals; values are typically given as arithmetic means (Table 2). The data are for animals in which residues were detected (and so animals were known to have been exposed) and were alive at the time of capture. Data are scant and the only compound for which we found multiple studies was brodifacoum. The median liver brodifacoum concentrations across all species and studies was $2.0 \mu \mathrm{g} / \mathrm{g}$ wet weight but concentrations varied by more than 100 fold across species and studies (Table 2). Differences between studies may be due to multiple factors and are likely to be greater than variation within studies which probably more reflect biological differences in uptake and accumulation/retention. We are only aware of one published study with a substantial dataset on liver residues in multiple non-target small mammal species (Geduhn et al. 2014). In that study, variation in mean liver brodifacoum residues between non-target rodents, the group of species most likely to consume bait directly, was only 1.4 fold (Table 2). In contrast, differences between species in the proportion of animals with detected residues was greater; 3-4 fold more wood mice and bank voles had detectable residues than field voles (Table 1). It may be therefore that much of the within-study variation between species in contamination is due to differences in the likelihood of encountering bait. 
Table 1. Review of the literature addressing the exposure of non-target small mammals (NTSM) to first and second generation anticoagulant rodenticides (FGARs and SGARs).

\begin{tabular}{|c|c|c|c|c|c|}
\hline $\begin{array}{l}\text { Usage / spatial } \\
\text { scale }\end{array}$ & Treatment features ${ }^{1}$ & Species $^{2}$ & $\begin{array}{l}\% \text { animals } \\
\text { exposed }\end{array}$ & Remarks & Reference \\
\hline $\begin{array}{l}\text { PPP } \\
\text { Local scale }\end{array}$ & $\begin{array}{l}\text { Non-poisoned wheat } \\
\text { baits in bait box with } \\
\text { hopper tunnels }\end{array}$ & $\begin{array}{l}\text { Evidence of bait } \\
\text { consumption for : } \\
\text { grey squirrel, wood } \\
\text { mouse, Norway rat }\end{array}$ & & $\begin{array}{l}\text { Simulated warfarin treatment. } \\
\text { Bait consumption showed using } \\
\text { automatic camera }\end{array}$ & $\begin{array}{l}\text { (Wood and } \\
\text { Phillipson 1977) }\end{array}$ \\
\hline $\begin{array}{l}\text { Biocide } \\
\text { Local scale }\end{array}$ & $\begin{array}{l}\text { Controlled - bait } \\
\text { stations (SGARs }+ \\
\text { markers) placed in and } \\
\text { around farm buildings }\end{array}$ & $\begin{array}{l}\text { wood mouse: evidence of } \\
\text { exposure } \\
\text { bank vole and field vole: } \\
\text { no evidence of exposure }\end{array}$ & & $\begin{array}{l}\text { Decline in wood mouse } \\
\text { populations in treated areas. } \\
\text { No population effects evident } \\
\text { for voles. }\end{array}$ & $\begin{array}{l}\text { (Cox and Smith } \\
\text { 1990) }\end{array}$ \\
\hline $\begin{array}{l}\text { Biocide } \\
\text { Local scale } \\
\left(\sim 0.03 \mathrm{~km}^{2}\right)\end{array}$ & $\begin{array}{l}\text { Controlled - Bait } \\
\text { stations (SGARs + } \\
\text { markers) placed in and } \\
\text { around farm buildings }\end{array}$ & $\begin{array}{l}\text { house mouse } \\
\text { Sorex spp. } \\
\text { wood mouse } \\
\text { bank vole } \\
\text { yellow-necked mouse }\end{array}$ & $\begin{array}{l}62 \% \\
30 \% \\
27 \% \\
8 \% \\
0 \%\end{array}$ & $\begin{array}{l}\text { Bait markers were detected in } \\
26 \% \text { of the NTSM trapped. }\end{array}$ & $\begin{array}{l}\text { (Townsend et al. } \\
1995 \text { ) }\end{array}$ \\
\hline $\begin{array}{l}\text { Biocide } \\
\text { Local scale } \\
(\sim 0.002 \text { to } 0.02 \\
\left.\mathrm{km}^{2}\right)\end{array}$ & $\begin{array}{l}\text { Controlled - Bait } \\
\text { stations placed (FGARs } \\
\text { + markers) around farm } \\
\text { buildings, around } \\
\text { pheasant- feed hoppers }\end{array}$ & $\begin{array}{l}\text { wood mouse } \\
\text { bank vole } \\
\text { house mouse } \\
\text { field vole }\end{array}$ & $\begin{array}{l}57.4 \% \\
30.6 \% \\
30 \% \\
19.5 \%\end{array}$ & $\begin{array}{l}\text { Exposure evidence in } 49 \% \text { of } \\
\text { individuals of NTSM species. } \\
\text { Impact on and recovery of } \\
\text { NTSM populations were also } \\
\text { assessed. Exposure was detected } \\
\text { in shrews but not quantified. }\end{array}$ & $\begin{array}{l}\text { (Brakes and Smith } \\
\text { 2005) }\end{array}$ \\
\hline
\end{tabular}




\begin{tabular}{|c|c|c|c|c|c|}
\hline $\begin{array}{l}\text { Usage / spatial } \\
\text { scale }\end{array}$ & Treatment features ${ }^{1}$ & Species $^{2}$ & $\begin{array}{l}\text { \% animals } \\
\text { exposed }\end{array}$ & Remarks & Reference \\
\hline $\begin{array}{l}\text { Biocide and } \\
\text { PPP } \\
\text { Local scale }\end{array}$ & $\begin{array}{l}\text { Uncontrolled - SGARs } \\
\text { (biocide) and FGARs } \\
\text { (biocide and PPP) }\end{array}$ & $\begin{array}{l}\text { deer mouse, Baja mouse, } \\
\text { California mouse, cactus } \\
\text { mouse }\end{array}$ & $19 \%$ & $\begin{array}{l}\text { Exposure details not provided } \\
\text { by species. FGARs detected in } \\
\text { only one individual ( } 4 \% \text { of } \\
\text { animals sampled) }\end{array}$ & $\begin{array}{l}\text { (Lima and Salmon } \\
\text { 2010) }\end{array}$ \\
\hline $\begin{array}{l}\text { Biocide } \\
\text { Local scale } \\
\left(\sim 0.2 \mathrm{~km}^{2}\right)\end{array}$ & $\begin{array}{l}\text { Controlled - Bait } \\
\text { stations (SGARs) placed } \\
\text { in and around farm } \\
\text { buildings }\end{array}$ & $\begin{array}{l}\text { house mouse } \\
\text { wood mouse }\end{array}$ & $\begin{array}{l}33.3 \% \\
14.5 \%\end{array}$ & $\begin{array}{l}\text { Distance to treatments was also } \\
\text { considered. Absence of effects } \\
\text { on populations. }\end{array}$ & (Tosh et al. 2012) \\
\hline $\begin{array}{l}\text { PPP } \\
\text { Local scale } \\
\left(0.17 \mathrm{~km}^{2}\right)\end{array}$ & $\begin{array}{l}\text { Controlled - Grain baits } \\
\text { (FGAR) applied in plots }\end{array}$ & $\begin{array}{l}\text { black-tailed prairie dog } \\
\text { thirteen-lined ground } \\
\text { squirrel }\end{array}$ & $\begin{array}{l}100 \% \\
100 \%\end{array}$ & $\begin{array}{l}\text { Small sample size (Black-tailed } \\
\text { prairie dog: } n=12 \text {; } \\
\text { thirteen-lined ground squirrel: } \\
n=2\end{array}$ & $\begin{array}{l}\text { (Vyas and Rattner } \\
\text { 2012) }\end{array}$ \\
\hline $\begin{array}{l}\text { Local scale } \\
\left(\sim 0.03 \mathrm{~km}^{2}\right)\end{array}$ & $\begin{array}{l}\text { Controlled - Bait } \\
\text { stations (SGARs) placed } \\
\text { in farm buildings }\end{array}$ & $\begin{array}{l}\text { Norway rat: } \\
\text { vole } \\
\text { deer mouse } \\
\text { shrew }\end{array}$ & $\begin{array}{l}60 \% \\
7 \% \\
0 \% \\
0 \%\end{array}$ & $\begin{array}{l}\text { All NTSM trapped along field } \\
\text { transects, none in buildings. } \\
\text { Small sample sizes for deer } \\
\text { mouse }(n=3) \text { and shrew }(n=6) .\end{array}$ & (Elliott et al. 2014) \\
\hline $\begin{array}{l}\text { Biocide } \\
\text { Local scale } \\
\left(0.03 \mathrm{~km}^{2}\right)\end{array}$ & $\begin{array}{l}\text { Controlled - Bait } \\
\text { stations (SGARs) placed } \\
\text { in and around farm } \\
\text { buildings }\end{array}$ & $\begin{array}{l}\text { Norway rat } \\
\text { house mouse } \\
\text { greater white-toothed shrew } \\
\text { Sorex spp } \\
\text { bank vole } \\
\text { Apodemus spp } \\
\text { harvest mouse } \\
\text { Microtus spp }\end{array}$ & $\begin{array}{r}98 \% \\
87 \% \\
66 \% \\
28 \% \\
26 \% \\
21 \% \\
10 \% \\
7 \%\end{array}$ & $\begin{array}{l}\text { ARs residues were detected in } \\
22.6 \% \text { of } 742 \text { NTSM }\end{array}$ & $\begin{array}{l}\text { (Geduhn et al. } \\
\text { 2014) }\end{array}$ \\
\hline
\end{tabular}




\begin{tabular}{|c|c|c|c|c|c|}
\hline $\begin{array}{l}\text { Usage / spatial } \\
\text { scale }\end{array}$ & Treatment features ${ }^{1}$ & Species $^{2}$ & $\begin{array}{l}\% \text { animals } \\
\text { exposed }\end{array}$ & Remarks & Reference \\
\hline $\begin{array}{l}\text { PPP } \\
\text { Local scale } \\
\left(0.03 \mathrm{~km}^{2}\right)\end{array}$ & $\begin{array}{l}\text { Controlled - Wheat } \\
\text { baits (SGARs) buried in } \\
\text { grassland }\end{array}$ & $\begin{array}{l}\text { water vole } \\
\text { common vole }\end{array}$ & $\begin{array}{l}99.6 \% \\
41 \%\end{array}$ & & (Sage et al. 2008) \\
\hline $\begin{array}{l}\text { Biocide } \\
\text { Local scale }(\sim 3 \\
\left.\mathrm{km}^{2}\right)\end{array}$ & $\begin{array}{l}\text { Uncontrolled (both } \\
\text { SGARS and FGARs } \\
\text { possible) }\end{array}$ & $\begin{array}{l}\text { Norway rat } \\
\text { house mouse } \\
\text { Apodemus ssp. } \\
\text { bank vole } \\
\text { common vole }\end{array}$ & $\begin{array}{l}67 \% \\
26 \% \\
6 \% \\
3 \% \\
3 \%\end{array}$ & $\begin{array}{l}\text { ARs residues were detected in } \\
8.2 \% \text { of the NTSM trapped }(n= \\
389)\end{array}$ & (Howald 1997) \\
\hline $\begin{array}{l}\text { PPP and } \\
\text { biocide } \\
\text { Local scale ( } 3 \\
\mathrm{~km}^{2} \text { ) }\end{array}$ & $\begin{array}{l}\text { Location / intensity } \\
\text { known for PPP } \\
\text { treatment (SGARs) } \\
\text { Uncontrolled for biocide } \\
\text { (both SGARS and } \\
\text { FGARs possible) }\end{array}$ & $\begin{array}{l}\text { house mouse } \\
\text { common vole } \\
\text { water vole: } \\
\text { Apodemus spp. } \\
\text { bank vole }\end{array}$ & $\begin{array}{l}100 \% \\
36 \% \\
20 \% \\
15 \% \\
15 \%\end{array}$ & $\begin{array}{l}\text { ARs residues were detected in } \\
19.2 \% \text { of the NTSM trapped (n } \\
=385)\end{array}$ & (Howald 1997) \\
\hline
\end{tabular}

${ }^{1}$ Treatments controlled or uncontrolled by researchers. Baits applied indoor and/or outdoor. ${ }^{2}$ wood mouse (Apodemus sylvaticus), yellow-necked mouse (Apodemus flavicollis), deer mouse (Peramyscus sp.), bank vole (Myodes glareolus), field vole (Microtus agrestis), common vole (Microtus arvalis), water vole (Arvicola scherman formerly Arvicola terrestris), vole (Microtus sp.), house mouse (Mus musculus), norway rat (Rattus norvegicus), harvest mouse (Micromys minutus), black-tailed prairie dog (Cynomys ludovicianus), thirteen-lined ground squirrel (Ictidomys tridecemlineatus), greater white-toothed shrew (Crocidura russula). Common names of target species are indicated in italics in the table. 
A key reason for quantifying residues in small mammals is to assess potential AR concentrations in the diet of predators and thereby estimate whether secondary exposure in predators may result in poisoning. Total body concentrations (TBCs) are usually more useful than liver residues when making such estimates because predators often consume the whole prey. However, data on anticoagulant TBCs in non-target small mammals trapped alive or found dead during field baiting studies is lacking. It may be possible to estimate TBCs from AR liver residues for SGARs as liver burdens have been shown to be good predictors of total body burden for bromadiolone in voles (Winters et al. 2010). Liver:TBC ratios have been reported in Microtus species (6.0, 8.8, and 5.2) and water vole (4.9) for bromadiolone (Giraudoux et al. 2006; Sage et al. 2008; Winters et al. 2010) and in poisoned laboratory mice (4.8) for brodifacoum (Newton et al. 1990). The median value of those five ratios (5.2) can be used to estimate TBCs in live-trapped animals for which liver residues were measured (Table 2). Overall, these data give an indication of the magnitude and variability of TBCs in nontarget species that may be available to predators.

Table 2. Measured liver residues and estimated Total Body Concentrations (TBCs) in non-target small mammals captured alive during baiting campaigns

\begin{tabular}{|c|c|c|c|c|c|}
\hline $\begin{array}{l}\text { Active } \\
\text { substance }\end{array}$ & Species $^{1}$ & $\begin{array}{l}\text { Number } \\
\text { animals }^{2}\end{array}$ & $\begin{array}{l}\text { Liver residue } \\
(\mu \mathrm{g} / \mathrm{g} \text { wet } w \mathrm{t})^{3}\end{array}$ & Ref & $\begin{array}{c}\text { Estimated TBC } \\
(\mu \mathrm{g} / \mathrm{g} \text { wet } w t)^{5}\end{array}$ \\
\hline Brodifacoum & wood mouse & 65 & 2.71 & 1 & 0.5 \\
\hline Brodifacoum & bank vole & 43 & 1.91 & 1 & 0.4 \\
\hline Brodifacoum & Microtus spp & 9 & 2.36 & 1 & 0.5 \\
\hline Brodifacoum & harvest mouse & 1 & 2.02 & 1 & 0.4 \\
\hline Brodifacoum & Sorex shrew & 25 & 0.21 & 1 & 0.0 \\
\hline Brodifacoum & Crocidura shrew & 25 & 0.57 & 1 & 0.1 \\
\hline Brodifacoum & vole (Microtus sp.) & 1 & 18.6 & 2 & 3.6 \\
\hline Brodifacoum & wood mice & 4 & 0.16 & 3 & 0.03 \\
\hline Flocoumafen & wood mice & 2 & 0.21 & 3 & 0.04 \\
\hline Difenacoum & wood mice & 1 & 0.02 & 3 & 0.004 \\
\hline Bromadiolone & wood mice & 2 & 0.02 & 3 & 0.004 \\
\hline
\end{tabular}

${ }^{1}$ Species as given in Table 1.

${ }^{2}$ Number of animals with detected residue

${ }^{3}$ Mean values for animals with detected residues only

${ }^{4}$ References are: 1. Geduhn et al. (2014); 2. Elliott et al. (2014); 3. Tosh et al. (2012)

${ }^{5}$ Estimated from liver residues using a liver:TBC ratio of 5.2. See text for details

TBCs appear to be generally greater in individuals and species when they are targets rather than non-targets. Microtus voles subject to control operations and that were captured alive during control campaigns had average brodifacoum TBCs of 4.07, 2.07 and $0.35 \mu \mathrm{g} / \mathrm{g}$ wet weight after applications at three different rates (Merson et al. 1984) and 0.76 and $0.13 \mu \mathrm{g} / \mathrm{g}$ wet weight bromadiolone after bromadiolone applications at two different rates (Winters et al. 2010). Water voles subject to bromadiolone control had TBCs of $1.22 \mu \mathrm{g} / \mathrm{g}$ (Giraudoux et al. 2006). These concentrations are generally higher than the estimated TBCs in non-target 
species that were likewise captured alive (Table 2). Furthermore, Ericsson and Urban (2004) reviewed a number of laboratory and field studies and collated data on wet weight TBCs in various commensal and non-commensal targets. TBCs varied across studies/species typically by approximately an order of magnitude (except for warfarin which varied by more than 100 fold) but median values were $2.5 \mu \mathrm{g} / \mathrm{g}$ for brodifacoum (derived from 14 datasets), $2 \mu \mathrm{g} / \mathrm{g}$ for bromadiolone (10 datasets), $2 \mu \mathrm{g} / \mathrm{g}$ for difethialone (single dataset), $0.75 \mu \mathrm{g} / \mathrm{g}$ for chlorophacinone (12 datasets), $1.2 \mu \mathrm{g} / \mathrm{g}$ wet weight for diphacinone (4 datasets) and $2.3 \mu \mathrm{g} / \mathrm{g}$ for warfarin (6 datasets). These TBCs in targets are again greater than those estimated for non-targets (Table 2). Given that residues generally are higher in target than non-target species, the dietary concentrations used in precautionary risk assessments of secondary poisoning of predators may be best based on TBCs in target species. The values collated by Ericsson and Urban (2004) are similar to those adopted by Luttik et al. (1999) when undertaking their assessment of secondary poisoning risk.

It is sometimes argued that scavengers may be more at risk from secondary poisoning than predators that predominantly take live prey. This, in part, may be because rodents that have died from poisoning have higher TBCs than live prey because surviving small mammals may only have been eaten sub-lethal amounts of bait. Consistent with this concept is the finding that bromadiolone total body burdens in Brandt's voles (Microtus brandti) from experimentally baited areas were some six-fold greater in voles found dead than in those captured alive (Winters et al. 2010). However, the occurrence of elevated residues in lethally poisoned prey is not so apparent from other studies. TBCs in Microtus spp. found dead following field baiting with brodifacoum were only $0.25-0.38 \mu \mathrm{g} / \mathrm{g}$ wet weight (Myllymäki et al. 1999). The mean TBC concentration in dead laboratory mice that had been poisoned with brodifacoum was likewise only $0.45 \mu \mathrm{g} / \mathrm{g}$ wet weight (Newton et al. 1990) and the brodifacoum TBC associated in rats and mice killed by a mean acute LD50 dose is estimated to be $0.33-0.58 \mu \mathrm{g} / \mathrm{g}$ (Luttik et al. 1999). These TBCs fall within the range of estimated values for live-trapped animals in Table 2. Data for bromadiolone are scanter than for brodifacoum but there was no difference in tissue concentrations in common voles (Microtus arvalis) trapped alive and those found dead (Sage et al. 2008). The mean bromadiolone TBC in the voles found dead was approximately $1 \mu \mathrm{g} / \mathrm{g}$ wet weight and the TBC associated with ingestion of a mean $\mathrm{LD}_{50}$ dose (laboratory rats and mice) has been estimated to be $0.75-0.86$ $\mu \mathrm{g} / \mathrm{g}$ wet weight (Luttik et al. 1999). These values are again within the range of TBCs found in live-tapped animals (Winters et al. 2010). Overall therefore, TBCs in exposed animals that have died may not necessarily differ markedly from those in animals from baited areas that have been exposed but have not [yet] died. This may be in part because lethally poisoned animals stop feeding before they die and have a gut empty of bait whereas live animals may have a full intestinal load of bait. Dietary AR residues may therefore be similar for predators and scavengers feeding on prey in baited areas, although empirical studies are needed to confirm whether this really is the case. Furthermore, the risk for animals that can and will scavenge may be enhanced simply through a relatively large availability of poisoned carcasses. 


\section{Causes of variation in anticoagulant rodenticide residues in non-target small mammals}

Perhaps the most striking aspects of the available data on exposure in non-target small mammals is the large scale variation both in the proportion of animals of each species that are exposed and the magnitude of residues that are accumulated. We suggested earlier in this chapter that some, or potentially much, of the within-study variation between species in residue accumulation may reflect differences in the likelihood of encountering bait and finding it palatable. However, it is the between study differences in contamination that are most striking (Table 2). These may be due to both abiotic and biotic factors and to differences in study design and methodology (Table 3). Some of these factors may also explain aspects of within-study variation in residue accumulation that occurs between individuals and between species.

Many of the abiotic factors that may influence primary exposure of non-targets centre on baiting practices and are likely to interact with biological traits. Timing of baiting, bait density, placement and protection, in conjunction with the habitat and dietary preferences of non-target species, may all influence which and when individuals and species are most likely to encounter and feed on bait. For example, higher population numbers and movements of rats into barns and buildings in the autumn (Feng and Himsworth 2014) leads to increased autumn use of rodenticides (Dawson et al. 2003; Garthwaite et al. 1999; Tosh et al. 2011) and may concomitantly increase the risk of primary exposure in non-target species. Bait placement may account for the lower extent of exposure in field voles compared with wood mice and bank voles in the study by Brakes and Smith (2005) as baits were placed close to rat burrows and in areas of concentrated rat activity, places unlikely to be favoured by field voles. Other salient biological factors that will influence extent of exposure include the relative availability and quality of non-bait food resources compared with bait, and the extent of intra and inter-specific competition for access to those resources. Mobility will also affect the likelihood of finding bait. Some species, such as the wood mouse, are highly mobile in agricultural systems and can explore over hundreds of metres per night (Macdonald et al. 2000; Wolton and Flowerdew 1985). Exposed mice can be found distant from bait stations (Geduhn et al. 2014; Tosh et al. 2012; Townsend et al. 1995) and effectively smear AR contamination across the wider landscape. Such spread is likely to be even more pronounced in primarily-exposed birds and in secondarily-exposed predatory birds and mammals that typically have relatively large foraging ranges. Spatial aspects of AR contamination in the landscape are discussed in more detail in Chapter 8. 
Table 3. Factors that may contribute towards variation between field studies in detected residue accumulation in non-target species

\begin{tabular}{lll}
\hline Abiotic & \multicolumn{1}{c}{ Biotic } & \multicolumn{1}{c}{ Methodological } \\
\hline Bait strength & $\begin{array}{l}\text { Temporal and spatial } \\
\text { variation in diet and habitat } \\
\text { selection }\end{array}$ & $\begin{array}{l}\text { Proximity of trapping to the } \\
\text { baited area }\end{array}$ \\
$\begin{array}{l}\text { Bait formulation and } \\
\text { palatability }\end{array}$ & $\begin{array}{l}\text { Relative abundance, } \\
\text { availability, palatability and } \\
\text { quality of non-bait food } \\
\text { sources vs bait food resources }\end{array}$ & $\begin{array}{l}\text { Time after baiting/exposure } \\
\text { that animals were sampled }\end{array}$ \\
$\begin{array}{l}\text { Density of baiting } \\
\text { points }\end{array}$ & $\begin{array}{l}\text { Inter and intra-specific } \\
\text { competition to access baits }\end{array}$ & $\begin{array}{l}\text { Inclusion of non-detected } \\
\text { values in summary statistics }\end{array}$ \\
$\begin{array}{l}\text { Physical ability to } \\
\text { access baits }\end{array}$ & $\begin{array}{l}\text { Tissue half- life of the } \\
\text { compound }\end{array}$ & $\begin{array}{l}\text { Inclusion of gut contents in } \\
\text { reported residue }\end{array}$ \\
Baiting duration & $\begin{array}{l}\text { Sampling efficiency varies } \\
\text { with degree of intoxication }\end{array}$ & $\begin{array}{l}\text { Recovery correction of } \\
\text { residues }\end{array}$ \\
& & $\begin{array}{l}\text { Selection of summary statistics } \\
\text { (eg., means vs medians) }\end{array}$ \\
\hline
\end{tabular}

Once bait is accessed, its composition, palatability and strength (amount of active ingredient in bait) are likely to affect the magnitude of total dose that is ingested by non-targets. In comparative studies where baits of different strength have been deployed, the largest residues have been found in animals from areas in which the strongest baits were used, although the relationship between the application rate and tissue residues is not proportionate or constant (Merson et al. 1984; Winters et al. 2010; Ericsson and Urban 2004). The duration of baiting, including whether baits are removed at the end of the control period, is also a likely major factor affecting the magnitude and persistence of primary exposure amongst non-target species. Audit schemes designed to ensure food is free from detectable rodent contamination (hair, faeces, other tissues) are commonplace in the food supply and distribution industries and inadvertently encourage prophylactic control measures that verge on permanent baiting (Smith and Shore 2015). Even when baiting is periodic, uneaten baits may not be removed at the end of the control period (Tosh et al. 2011). Long-term availability of baits is likely to lead to continuous exposure of non-target species. In addition, baits may also be cached by non-target small mammals and accessed at a later period after active baiting has ceased (Brakes and Smith 2005).

Although primary exposure can only occur when bait is available to eat, tissue residues persist for longer. This is because some ARs have relatively long tissue half-lives, although these vary markedly between compounds and particularly between first and second- 
generation rodenticides. For example, the plasma and liver half-lives of the first generation anticoagulant rodenticide (FGAR) chlorophacinone are reported to be 0.52 days and 15.8 days respectively whereas the equivalent values for the second-generation brodifacoum are 91.7 days and 307.4 days (Vandenbroucke et al. 2008). This variation in persistence does not affect exposure per se but rather the extent of bioaccumulation in tissues and the period over which residues arising from primary exposure are detectable. Sub-lethally exposed non-target animals may potentially carry tissue residues of some ARs, such as brodifacoum, for months after exposure occurred.

One other biological factor that can influence the detection of exposure is that intoxication with rodenticides can affect behaviour in rodents (Cox and Smith 1992). Such altered behaviour may affect the propensity of animals to be captured in traps, result in non-random sampling of the population for residue analysis, and bias estimates of exposure in the population. Such potential biases likewise apply to studies that characterise secondary exposure by measuring residues in predators that have been deliberately or accidentally killed. However, we are unaware of any detailed dose-response studies that relate extent of exposure to likelihood of capture in traps or other aspects of behaviour, nor is it known whether intoxication is more likely to lead to an increase or a decrease (or in fact no effect) in likelihood of capture. Comparison of data with that collected using other techniques is not easy. Non-toxic bait markers can be used to characterise bait take (Townsend et al. 1995) but these studies assume ingestion of rodenticide does not affect subsequent feeding behaviour, while direct observation of bait take is difficult to quantify in terms of how many different individuals attend bait stations and how much each eats. Collection of carcasses and associated residue analyses is problematic for different reasons, namely bodies are rapidly removed by scavengers (Montaz et al. 2014), many animals die underground (Howald et al. 1999) and collected carcasses are only representative of exposure in lethally poisoned animals. Overall therefore, it is clear that any measure of the extent of primary exposure in non-targets may be open to bias. This introduces uncertainty when such data from sampled individuals are used directly as estimates of the extent of exposure in the population as a whole.

Perhaps surprisingly, there is a wide variety of methodological factors that, while not altering primary exposure per se in non-target species, can affect the reporting of its scale and magnitude, and so account for differences between field studies in detected exposures. Generally, these factors are equally applicable to studies of secondary exposure (Chapter 7) and often to contaminant studies in general. Some factors are intrinsic components of study design and include the proximity of trapping to baiting areas and the timing of sampling relative to onset of baiting; both tend to vary between individual studies. The extent of exposure in non-target small mammals has been found to decline with distance from baited areas (Geduhn et al. 2014; Townsend et al. 1995; Jacquot et al. 2013) and exposure would likewise be expected to decline following cessation of baiting. Tosh et al. (2012) attributed the relatively low detection of contamination in non-targets on farms in their study partly to the fact that trapping was only conducted 6-8 weeks after onset of baiting campaigns. The rate at which detectability of exposure declines following cessation in baiting is likely to be related to the tissue half-life of the AR and to the extent of immigration by non-exposed animals that may occur into baited areas. 
Other methodological factors that contribute to the apparent variability between studies in residue magnitude can often be standardised to some extent or normalised provided that sufficient ancillary data are provided. One such factor is whether the gut contents (which may contain bait) are included in any reporting of TBCs. Gut contents may comprise a significant portion of the total body burden and be an important component of the risk associated with secondary exposure to contaminants (Walker et al. 2002). Ideally AR burdens in the gut content should be reported separately from concentrations for the rest of the carcass so that TBCs with and without the gut contents can be calculated; such separation of data is also useful when calculating biomagnification factors (van den Brink et al. 2016). The way in which residue data are calculated and summarised can also have a major impact on the magnitude of residues reported. Residue data for rodenticides are normally reported on a wet weight basis and so conversion between wet, dry or lipid weight based concentrations are rarely necessary. However, studies do differ in their limits of detection and whether residue data are corrected for analytical recovery. Information on limits of quantification and analytical recoveries should always be provided. In terms of data presentation, some studies present summary statistics, such as average residue magnitudes, based only on animals that contain detected residues while others may report averages based on the whole sample including animals with non-detected values. It is usually possible to correct and compare values across studies, at least in terms of mean values, provided the percentage of the sample with non-detected values is given. However, choice of the arithmetic mean as a summary statistic can be an issue. As with many contaminant residue data, the distribution of AR residues in animal tissues is typically non-normal and strongly right skewed. Consequently, arithmetic mean values can markedly exceed other summary measures such as medians, and differences can be as large as 50-fold (Geduhn et al. 2014). Simple comparisons between studies therefore need to be on the basis of the same summary metric and this is facilitated if studies provide raw residue data and/or a range of different summary statistics. Given the availability of electronic supplements, we advocate that authors make such data available with their publications.

\section{Resistance and implications for primary exposure of non-target species}

Most of the interest in the development of resistance to ARs in rodents has naturally been focussed on target species as this presents a significant challenge to the efficacy of rodent control. There is now widespread resistance to FGARs amongst target species and developing resistance to some SGARs such as bromadiolone and difenacoum (Meerburg et al. 2014; Buckle 2013; Endepols et al. 2012; Baert et al. 2012; Pelz and Prescott 2015).

We are not aware of resistance in species that can be strictly considered non-targets and this may reflect that fact that these species are not deliberately controlled and so do not face severe selection pressure for resistant genotypes. However, there are some reports of resistance developing in species that are controlled in some areas but would be considered non-targets elsewhere. Specifically, the indandione rodenticides chlorophacinone and diphacinone have been found to be becoming less effective in controlling populations of California voles (Microtus californicus) in agricultural areas. It is uncertain whether this is due to genetic or physiological resistance, a reduced effectiveness of these compounds in 
voles selecting diet rich in vitamin $\mathrm{K}$, or changed palatability or formulation issues with the currently used commercial baits (Witmer et al. 2014). There have also been reports of potential development of resistance in water voles in agricultural grassland areas of France where this species is subject to control using bromadiolone. Enzymatic and genetic studies on animals from treated and non-treated plots indicated that water voles from the most heavily treated areas exhibit enzymatic changes in Vitamin K epoxide reductase and may be a basis for the development of resistance (Vein et al. 2011). The likelihood of any genetic resistance in voles spreading throughout wider populations not subject to intense control activities would at least in part depend on whether there are significant adverse pleiotropic effects associated with the resistance trait (Pelz and Prescott 2015).

Although non-target species may not themselves have become resistant to ARs, they may be affected indirectly by resistance in target species. The development of FGAR resistance, and in fact fear of such development, in rats and house mice has been a major driver in the global adoption of SGARs which are more acutely toxic (WHO 1995; Ericsson and Urban 2004). Incidental feeding by non-target species on baits that contain SGARs rather than FGARs is more likely to result in mortality. The switch from FGARs to SGARs may have had more impact on birds than non-target mammals as the difference in acute toxicity between FGARS and SGARs is generally greater in birds than mammals (Ericsson and Urban 2004). Development of SGAR (bromadiolone and difenacoum) resistance in rats may also have indirect effects on non-targets. There are anecdotal reports that, in areas of the UK in which Norway rats are known to be resistant to bromadiolone and difenacoum, users undertake prolonged and intensive baiting with these compounds as they struggle to control rat infestations. UK restrictions prevented around building or open area use of alternative SGARs (brodifacoum, flocoumafen and difethialone) to which there is no evidence of resistance to date. Any such prolonged and intensive baiting with bromadiolone and difenacoum is likely to enhance the risk of exposure and poisoning of non-target species, although there do not appear to have been any investigations of such effects. Changes in UK regulations in 2016 mean that "around building" use of brodifacoum, flocoumafen and difethialone are now permissible and may reduce the incidence of prolonged baiting, although any widescale switch to the most potent SGARs could, in itself, pose an increased risk of primary poisoning to non-target species.

\section{Evidence of ecologically significant effects in non-target species from primary exposure}

It has been generally thought that exposure of invertebrates to ARs is unlikely to be associated with adverse effects because of the differences in blood-clotting systems between vertebrates and invertebrates (Loof et al. 2011). However, it is possible that there may be other toxic modes of action induced by ARs in invertebrates. A recent study found that experimental exposure of the earthworm (Eisenia foetida) to environmentally realistic soil concentrations of bromadiolone resulted in low bioaccumulation in worms $(0.03$ BSAFs < 0.10), significant inhibition of their growth and induction of lipid peroxidation (Liu et al. 2015). Furthermore, a study of the effects of brodifacoum rodent control on snails, insects and millipedes in 1999 on Fregate Island in the Seychelles indicated that all species would 
consume bait and, while there was no apparent adverse effect on arthropods, two snail species (Achatina fulica, Pachnodus silhouettanus) suffered $100 \%$ mortality (Gerlach and Florens 2000). The authors of this study also reported observations made in Mauritius in which 24 ha of forest were subjects to rodent control with brodifacoum. Various snail species were seen feeding on poison baits. It is reported that statistically significantly higher numbers of recently dead Pachystyla bicolor and lower numbers of live adults were found in baited than non-baited areas. The occurrence, scale and ecological significance of any such AR-induced effects in invertebrates in the natural environment are unknown and warrant further investigation. However, the cost-benefit ratio of rat eradication programmes to island snail populations is likely to depend on the level of rat predation on the snails (Gerlach and Florens 2000).

In terms of the impacts of ARs on vertebrate non-target species, Ericsson and Urban (2004) summarised data from experimental studies conducted outdoors and from operational control programmes. Such studies and programmes clearly demonstrate that mortalities do occur amongst non-target vertebrates that feed directly on bait. A key question though is whether such mortalities translate into ecologically significant impacts such as reductions in populations.

The effects of some intensive island control operations in New Zealand using brodifacoum have been reviewed by Eason and Spurr (1995). They reported large reductions in numbers $(>90 \%)$ or total extirpation of wekas (Gallirallus australus) and pukeko (Porphyrio porphyrio), two indigenous rail species, during some rat control campaigns. Declines in passerine species also occurred during other island eradications. A rat control programme using brodifacoum on a Canadian island caused a population decline in dusky shrews (Sorex monticolus) which entered bait stations and fed directly on bait (Howald 1997 cited in Ericsson and Urban 2004). However, the long-term effects on populations were unclear as populations rebounded to some extent after baiting stopped.

There have been a few studies of the impacts of rat-control operations on non-target small mammal populations on mainland agricultural premises. Geduhn et al. (2014) found that there was a decrease in the numbers of wood mice captured within $15 \mathrm{~m}$ of bait stations during rat control programmes that used brodifacoum on German farms. Likewise Cox and Smith (1990) estimated that survivorship of wood mice around areas of "in and around building" rat control on UK farms using bromadiolone was 0-19\% and populations decreased whereas survivorship on control sites was $50 \%$ and there was little change in population numbers. In a later, more comprehensive, study Brakes and Smith (2005) found that populations of non-target small mammals, such as wood mice and bank voles, declined by on average $60 \%$ as a result of rat control operations with chlorophacinone. Populations partially recovered three months after cessation of treatment, although this depended on when control operations were conducted relative to the breeding cycle. Sage et al. (2008) also noted a decline in common vole populations in grasslands baited with bromadiolone to control water vole numbers. In contrast, Tosh et al. (2012) found no effect on Northern Irish farms of ratcontrol treatment on population changes in wood mice when these were examined 6-10 weeks after the start of autumn treatments that used a variety of SGARs. The authors suggested that any localised effects of rodenticides on wood mouse abundance may have been quickly offset by immigration from surrounding areas. 
We are unaware of any evidence that primary exposure of vertebrate non-targets results in sub-lethal effects that impact longer-term survival, reproduction or immigration. The evidence to date suggests that the main direct impact of ARs is to cause acute mortalities. These can lead to reductions in populations, particularly on islands where numbers may be relatively small, baiting extensive, and there is limited or no potential for immigration. The risks of such effects have been recognised and mitigation measures proposed, such as temporarily removing animals from areas during baiting campaigns so as to prevent exposure (Wanless et al. 2010). On mainland areas, the geographical extent and duration of any rodenticide-mediated population depression is likely to depend on a variety of factors. These include scale, duration and timing of application, habitat connectivity (which may affect potential for immigration), and intrinsic rate of population growth which is typically linked to life history strategy. Most non-target species that can readily access bait are likely to be $r$ selected species. Although such species may suffer population declines as a result of primary exposure to rodenticides, these declines are likely to be relatively short-term provided that baiting is episodic. This is because populations may recover through rapid reproduction by survivors, reduced density-dependent mortality, and immigration. Wood mouse populations, for example, appear to be relatively resilient in the long-term not only to population declines induced by exposure to rodenticides, but also to much wider field-scale mortalities induced by other biocides such as molluscicides (Johnson et al. 1991). However, in areas where permanent AR baiting occurs, there may potentially be a permanent depletion of resident populations of non-target species. Any such depletion could be ameliorated by immigration but such areas may then effectively act as population sinks.

\section{Conclusions}

Primary exposure of a range of non-target insect, reptile, bird and mammal species clearly does occur. This is evident from published studies and also from secondary exposure studies (Chapter 7) that indicate there is transfer of ARs through multiple trophic pathways. The extent (range of species, proportion of individuals exposed, magnitude of residues) of apparent non-target primary exposure that is detected can be highly variable. This variability is influenced by a range of factors that affect true exposure but study methodologies also influence the extent to which exposure is actually quantified.

The significance of secondary exposure to ARs in terms of potential to cause toxicity and associated ecologically significant effects is subject to debate and investigation (Rattner et al. 2014). Arguably, primary exposure is more likely than secondary exposure to cause acute mortalities. Bait is placed in sufficient quantities to elicit mass mortality in pest species and so presumably has similar potential to cause death in non-targets that take bait. However, effects on non-target populations may typically be relatively transient except where baiting is permanent or in areas where immigration is limited.

There are various major uncertainties and gaps in information about primary exposure in nontarget species. These include better determination of the occurrence of exposure and associated impacts of ARs in both reptiles and invertebrates. Furthermore, many ecological communities contain more insectivorous vertebrates than predators (Dowding et al. 2010) and so it is important to determine whether, as the scant data available to date suggest, small 
insectivores are particularly susceptible to AR exposure. This may be because insectivores are susceptible to both primary and secondary exposure pathways, and highlights the need to examine all potential exposure pathways when assessing risk. The lack of understanding about the potential direct and indirect effects of AR resistance on non-target exposure also remains a pressing research need especially if resistance to SGARs continues to increase. Finally, we have focussed in this chapter on the risk of primary exposure to non-target species that largely occur in semi-rural and rural habitats. Rodenticides are widely used in urban environments (Murphy and Oldbury 2002; Morzillo and Mertig 2011) and are likely to pose a primary exposure risk to urban wildlife. Residues have also been detected in urban waste waters (Gomez-Canela et al. 2014), presumably originating from surface run-off from baits, use of ARs in sewers, and excretion of ARs used therapeutically in humans. While there have been studies of AR exposure in some urban predators (Albert et al. 2010; Hindmarch and Elliott 2014; Riley et al. 2007; Serieys et al. 2015; Thomas et al. 2011), we are unaware of detailed studies of primary exposure in non-target wildlife from urban areas in both terrestrial and freshwater environments. It is just possible that any effects on non-target populations may be greatest in such habitats. Investigation of the scale of exposure and associated effects arising from both primary and secondary exposure in urban areas are needed. 


\section{References}

Albert CA, Wilson LK, Mineau P, Trudeau S, Elliott JE (2010) Anticoagulant Rodenticides in Three Owl Species from Western Canada, 1988-2003. Arch Environ Contam Toxicol 58 (2):451-459. doi:10.1007/s00244-009-9402-z

Baert K, Stuyck J, Breyne P, Maes D, Casaer J (2012) Distribution of anticoagulant resistance in the brown rat in Belgium. Belgian Journal of Zoology 142 (1):39-48

Baldwin RA, Quinn N, Davis DH, Engeman RM (2014) Effectiveness of rodenticides for managing invasive roof rats and native deer mice in orchards. Environmental Science and Pollution Research 21 (9):5795-5802. doi:10.1007/s11356-014-2525-4

Berny P, Alves L, Simon V, Rossi S (2005) Anticoagulant rodenticide poisoning in ruminants: evidence from field cases. Revue De Medecine Veterinaire 156 (8-9):449454

Berny P, Esther A, Jacob J, Prescott C (2014) Risk mitigation measures for anticoagulant rodenticides as biocidal products: final report. European Union, Luxembourg, pp.104. doi:10.2779/241180; https://circabc.europa.eu/sd/a/352bffd8-babc-4af8-9d0ca1c87a3c3afc/Final\%20Report\%20RMM.pdf

Berny P, Mastain O, Decors A, Poulsen V, Moinet M, Dunoyer C (2010a) The SAGIR network in France: A 40-year active and passive toxicovigilance scheme for pesticide poisoning in wildlife. Toxicology Letters 196:S322-S322. doi:10.1016/j.toxlet.2010.03.1017

Berny P, Velardo J, Pulce C, D'Amico A, Kammerer M, Lasseur R (2010b) Prevalence of anticoagulant rodenticide poisoning in humans and animals in France and substances involved. Clinical Toxicology 48 (9):935-941. doi:10.3109/15563650.2010.533678

Bowie MH, Ross JG (2006) Identification of weta foraging on brodifacoum bait and the risk of secondary poisoning for birds on Quail Island, Canterbury, New Zealand. N Z J Ecol 30 (2):219-228

Brakes CR, Smith RH (2005) Exposure of non-target small mammals to rodenticides: shortterm effects, recovery and implications for secondary poisoning. J Appl Ecol 42 (1):118-128

Brown P, Charlton A, Cuthbert M, Barnett L, Ross L, Green M, Gillies L, Shaw K, Fletcher M (1996) Identification of pesticide poisoning in wildlife. J Chromatogr A 754 (12):463-478

Buckle A (2013) Anticoagulant resistance in the United Kingdom and a new guideline for the management of resistant infestations of Norway rats (Rattus norvegicus Berk.). Pest Manag Sci 69 (3):334-341. doi:10.1002/ps.3309

Buckle AP, Eason CT (2015) Control methods:chemical. In: Buckle AP, Smith RH (eds) Rodent pests and their Control, 2nd edition. CAB International, Wallingford, pp 123154

Capizzi D, Bertolino S, Mortelliti A (2014) Rating the rat: global patterns and research priorities in impacts and management of rodent pests. Mamm Rev 44 (2):148-162. doi:10.1111/mam.12019

Coeurdassier M, Poirson C, Paul JP, Rieffel D, Michelat D, Reymond D, Legay P, Giraudoux P, Scheifler R (2012) The diet of migrant Red Kites Milvus milvus during a Water Vole Arvicola terrestris outbreak in eastern France and the associated risk of secondary poisoning by the rodenticide bromadiolone. Ibis 154 (1):136-146. doi:doi: 10.1111/j.1474-919X.2011.01193.x

Cox P, Smith RH Rodenticide ecotoxicology: Pre-lethal effects of anticoagulants on rat behaviour. In: Borrecco JE, Marsh RE (eds) 15th Vertebrate Pest Conference, University of California, Davis, 1992. pp 165-170 
Cox PR, Smith RH (1990) Rodenticide ecotoxicology - assessing nontarget population effects. Funct Ecol 4 (3):315-320

Dawson A, Bankes J, Garthwaite DG (2003) Pesticide Usage Survey Report 175:

Rodenticide usage on farms in Great Britain growing arable crops 2000. MAFF Publications, London

Dennis GC, Gartrell BD (2015) Nontarget mortality of New Zealand lesser short-tailed bats (Mystacina tuberculata) caused by diphacinone. J Wildl Dis 51 (1):177-186. doi:10.7580/2013-07-160

Doolittle RF, Feng DF (1987) RReconstructing the evolution of vertebrate blood-coagulation from a consideration of the amino-acid sequences of clotting proteins. Cold Spring Harbor Symp Quant Biol 52:869-874

Dowding CV, Shore RF, Worgan A, Baker PJ, Harris S (2010) Accumulation of anticoagulant rodenticides in a non-target insectivore, the European hedgehog (Erinaceus europaeus). Environ Pollut 158 (1):161-166. doi:10.1016/j.envpol.2009.07.017

Eason CT, Spurr EB (1995) Review of the toxicity and impacts of brodifacoum on non-target wildlife in New Zealand. New Zealand Journal of Zoology 22 (4):371-379

Elliott JE, Hindmarch S, Albert CA, Emery J, Mineau P, Maisonneuve F (2014) Exposure pathways of anticoagulant rodenticides to nontarget wildlife. Environ Monit Assess 186 (2):895-906. doi:10.1007/s10661-013-3422-x

Endepols S, Klemann N, Jacob J, Buckle AP (2012) Resistance tests and field trials with bromadiolone for the control of Norway rats (Rattus norvegicus) on farms in Westphalia, Germany. Pest Manag Sci 68 (3):348-354. doi:10.1002/ps.2268

Ericsson W, Urban D (2004) Potential risks of nine rodenticides to birds and non-traget mammals: a comparative approach. United States Environmental Protection Agency, http://www.fwspubs.org/doi/suppl/10.3996/052012-JFWM042/suppl_file/10.3996_052012-jfwm-042.s4.pdf, Washington DC

Feng AYT, Himsworth CG (2014) The secret life of the city rat: a review of the ecology of urban Norway and black rats (Rattus norvegicus and Rattus rattus). Urban Ecosystems 17 (1):149-162. doi:10.1007/s11252-013-0305-4

Garthwaite DG, De'Ath A, Thomas MR (1999) Pesticide Usage Survey Report 154: Rodenticide usage in Great Britain on farms growing grassland and fodder crops 1997. MAFF Publications, London

Geduhn A, Esther A, Schenke D, Mattes H, Jacob J (2014) Spatial and temporal exposure patterns in non-target small mammals during brodifacoum rat control. Science of the Total Environment 496:328-338. doi:10.1016/j.scitotenv.2014.07.049

Gerlach J, Florens V (2000) Considering molluscs in rodent eradication projects. Tentacle-the newsletter of the IUCN/SSC mollusc specialist group http://wwwhawaiiedu/cowielab/tentacle/tentacle_9pdf Last accessed 05 December, 2015 9:7-8

Giraudoux P, Tremollieres C, Barbier B, Defaut R, Rieffel D, Bernard N, Lucota E, Berny P (2006) Persistence of bromadiolone anticoagulant rodenticide in Arvicola terrestris populations after field control. Environ Res 102 (3):291-298. doi:10.1016/j.envres.2006.02.008

Gomez-Canela C, Barata C, Lacorte S (2014) Occurrence, elimination, and risk of anticoagulant rodenticides and drugs during wastewater treatment. Environmental Science and Pollution Research 21 (11):7194-7203. doi:10.1007/s11356-014-2714-1 
Hardy AR, Fletcher MR, Stanley PI (1986) Pesticides and wildlife: Twenty years of vertebrate wildlife incidence investigations by MAFF. State Veterinary Journal 40:182-192

Harris S, Yalden DW (eds) (2008) Mammals of the British Isles: Handbbok. 4th edition. The Mammal Society, Southampton

Hindmarch S, Elliott JE (2014) Comparing the diet of great horned owls (Bubo virginianus) in rural and urban areas of southwestern British Columbia. Can Field-Nat 128 (4):393-399

Hoare JM, Hare KM (2006) The impact of brodifacoum on non-target wildlife: gaps in knowledge. N Z J Ecol 30 (2):157-167

Howald G (1997) The risk of non-target species poisoning from brodifacoum used to eradicate rats from langara Island, British columbia, Canada. MS Thesis, University of British Columbia, Vancouver, BC, 159pp

Howald G, Ross J, Buckle AP (2015) Rodent control and island conservation. In: Buckle AP, Smith RH (eds) Rodent pests and their Control, 2nd edition. CAB International, Wallingford, pp 366-396

Howald GR, Mineau P, Elliott JE, Cheng KM (1999) Brodifacoum poisoning of avian scavengers during rat control on a seabird colony. Ecotoxicology 8 (6):431-447

Jacquot M, Coeurdassier M, Couval G, Renaude R, Pleydell D, Truchetet D, Raoul F, Giraudoux P (2013) Using long-term monitoring of red fox populations to assess changes in rodent control practices. J Appl Ecol 50 (6):1406-1414. doi:10.1111/13652664.12151

Johnson IP, Flowerdew JR, Hare R (1991) Effects of broadcasting and of drilling methiocarb molluscicide pellets on field populations of wood mice, Apodemus sylvaticus. Bull Environ Contam Toxicol 46:84-91

Jokic G, Vuksa M, Elezovic I, Dedovic S, Kataranovski D (2012) Application of grain baits to control common vole Microtus arvalis (Pallas, 1778) in alfalfa crops, Serbia. Archives of Biological Sciences 64 (2):629-637. doi:10.2298/abs1202629j

Khan AA, Munir S, Shakoori AR (1998) Development of under-ground baiting technique for control of rats in rice fields in Pakistan. Int Biodeterior Biodegrad 42 (2-3):129-134. doi:10.1016/s0964-8305(98)00007-9

Lima LL, Salmon TP (2010) Assessing some potential environmental impacts from agricultural anticoagulant uses. Proceedings of the Vertebrate Pest Conference 24:199-203

Liu J, Xiong K, Ye X, Zhang J, Yang Y, Ji L (2015) Toxicity and bioaccumulation of bromadiolone to earthworm Eisenia fetida. Chemosphere 135:250-256. doi:10.1016/j.chemosphere.2015.04.058

Loof TG, Schmidt O, Herwald H, Theopold U (2011) Coagulation Systems of Invertebrates and Vertebrates and Their Roles in Innate Immunity: The Same Side of Two Coins? Journal of Innate Immunity 3 (1):34-40. doi:10.1159/000321641

Lopez-Perea JJ, Camarero PR, Molina-Lopez RA, Parpal L, Obon E, Sola J, Mateo R (2015) Interspecific and geographical differences in anticoagulant rodenticide residues of predatory wildlife from the Mediterranean region of Spain. Science of the Total Environment 511:259-267. doi:10.1016/j.scitotenv.2014.12.042

Lund M (2015) Commensal rodents. In: Buckle AP, Smith RH (eds) Rodent pests and their Control, 2nd edition. CAB International, Wallingford, pp 19-32 
Luque-Larena JJ, Mougeot F, Vinuela J, Jareno D, Arroyo L, Lambin X, Arroyo B (2013) Recent large-scale range expansion and outbreaks of the common vole (Microtus arvalis) in NW Spain. Basic and Applied Ecology 14 (5):432-441. doi:10.1016/j.baae.2013.04.006

Luttik R, Clook MA, Taylor MR, Hart ADM (1999) Regulatory aspects of the ecotoxicological risk assessment of rodenticides. In: Cowan DP, Feare CJ (eds) Advances in vertebrate pest management. Filander Verlag, Fürth, pp 369-385

Macdonald DW, Tew TE, Todd IA, Garner JP, Johnson PJ (2000) Arable habitat use by wood mice (Apodemus sylvaticus). 3. A farm-scale experiment on the effects of crop rotation. J Zool 250:313-320

Masuda BM, Fisher P, Beaven B (2015) Residue profiles of brodifacoum in coastal marine species following an island rodent eradication. Ecotoxicol Environ Saf 113:1-8. doi:10.1016/j.ecoenv.2014.11.013

Masuda BM, Fisher P, Jamieson IG (2014) Anticoagulant rodenticide brodifacoum detected in dead nestlings of an insectivorous passerine. N Z J Ecol 38 (1):110-115

Meerburg BG, van Gent-Pelzer MPE, Schoelitsz B, van der Lee TAJ (2014) Distribution of anticoagulant rodenticide resistance in Rattus norvegicus in the Netherlands according to Vkorc1 mutations. Pest Manag Sci 70 (11):1761-1766. doi:10.1002/ps.3809

Merson MH, Byers RE, Kaukeinen DE (1984) Residues of the rodenticide brodifacoum in voles and raptors after orchard treatment. J Wildl Manage 48 (1):212-216

Meyer AN, Kaukeinen DE (2015) Rodent control in prcatice: protection of humans and animal health. In: Buckle AP, Smith RH (eds) Rodent pests and their Control, 2nd edition. CAB International, Wallingford, pp 231-246

Montaz J, Jacquot M, Coeurdassier M (2014) Scavenging of rodent carcasses following simulated mortality due to field applications of anticoagulant rodenticide. Ecotoxicology 23 (9):1671-1680. doi:10.1007/s10646-014-1306-7

Moran S (2001) The efficacy of the flocoumafen wax block bait to control the field rodents Microtus guentheri and Meriones tristrami. Crop Prot 20 (6):529-533

Morzillo AT, Mertig AG (2011) Urban resident attitudes toward rodents, rodent control products, and environmental effects. Urban Ecosystems 14 (2):243-260. doi:10.1007/s11252-010-0152-5

Murphy G, Oldbury DJ Rat control by local authorities within the United Kingdom. In: Jones SC, Zhai J, Robinson WH (eds) Fourth International Confernce on Urban Pests, Charleston, USA, 2002. pp 413-420

Myllymäki A, Pihlava J-H, Tuuri H (1999) Predicting the exposure and risk to predators and scavengers associated with using single-dose second-generation anticoagulants against field rodents. In: Cowan DP, Feare CJ (eds) Advances in vertebrate pest management. Filander Verlag, Fürth, pp 387-404

Newton I, Wyllie I, Freestone P (1990) Rodenticides in British barn owls. Environ Pollut 68 (1-2):101-117

Ogilvie SC, Pierce RJ, Wright GRG, Booth LH, Eason CT (1997) Brodifacoum residue analysis in water, soil, invertebrates, and birds after rat eradication on Lady Alice Island. N Z J Ecol 21 (2):195-197

Pain DJ, Brooke MD, Finnie JK, Jackson A (2000) Effects of brodifacoum on the land crab of Ascension island. J Wildl Manage 64 (2):380-387

Pelz H-J, Prescott CV (2015) Resistance to anticoagulant rodenticides. In: Buckle AP, Smith RH (eds) Rodent pests and their Control, 2nd edition. CAB International, Wallingford, pp 187-208 
Pitt WC, Berentsen AR, Shiels AB, Volker SF, Eisemann JD, Wegmann AS, Howald GR (2015) Non-target species mortality and the measurement of brodifacoum rodenticide residues after a rat (Rattus rattus) eradication on Palmyra Atoll, tropical Pacific. Biol Conserv 185:36-46. doi:10.1016/j.biocon.2015.01.008

Pryde MA, Pickerell G, Coats G, Hill GS, Greene TC, Murphy EC (2013) Observations of South Island Robins eating Racumin (R), a toxic paste used for rodent control. New Zealand Journal of Zoology 40 (3):255-259. doi:10.1080/03014223.2012.727442

Rattner BA, Lazarus RS, Elliott JE, Shore RF, van den Brink N (2014) Adverse Outcome Pathway and Risks of Anticoagulant Rodenticides to Predatory Wildlife. Environ Sci Technol 48 (15):8433-8445. doi:10.1021/es501740n

Riley SPD, Bromley C, Poppenga RH, Uzal FA, Whited L, Sauvajot RM (2007) Anticoagulant exposure and notoedric mange in bobcats and mountain lions in urban southern California. J Wildl Manage 71 (6):1874-1884. doi:10.2193/2005-615

Ruder MG, Poppenga RH, Bryan JA, Bain M, Pitman J, Keel MK (2011) Intoxication of Nontarget Wildlife with Rodenticides in Northwestern Kansas. J Wildl Dis 47 (1):212-216

Sage M, Coeurdassier M, Defaut R, Gimbert F, Berny P, Giraudoux P (2008) Kinetics of bromadiolone in rodent populations and implications for predators after field control of the water vole, Arvicola terrestris. Science of the Total Environment 407 (1):211222. doi:10.1016/j.scitotenv.2008.09.003

Salmon TP, Dochtermann NA (2006) Rodenticide grain bait ingredient acceptance by Norway rats (Rattus norvegicus), California ground squirrels (Spermophilus beecheyi) and pocket gophers (Thomomys bottae). Pest Manag Sci 62 (7):678-683. doi:10.1002/ps.1224

Sanchez-Barbudo IS, Camarero PR, Mateo R (2012) Primary and secondary poisoning by anticoagulant rodenticides of non-target animals in Spain. Science of the Total Environment 420:280-288. doi:10.1016/j.scitotenv.2012.01.028

Saucy F, Meylan A, Poitry R (2001) Lessons from 18 years of use of anticoagulants against fossorial Arvicola terrestris in Switzerland. In: Pelz H-J, Cowan DP, Feare CJ (eds) Advances in vertebrate pest management II. Filander Verlag, Fürth, pp 71-90

Serieys LEK, Armenta TC, Moriarty JG, Boydston EE, Lyren LM, Poppenga RH, Crooks KR, Wayne RK, Riley SPD (2015) Anticoagulant rodenticides in urban bobcats: exposure, risk factors and potential effects based on a 16-year study. Ecotoxicology 24 (4):844-862. doi:10.1007/s10646-015-1429-5

Shore RF, Pereira M.G., Potter ED, Walker LA (2015) Monitoring rodenticide residues in wildlife. In: Buckle AP, Smith RH (eds) Rodent pests and their Control, 2nd edition. CAB International, Wallingford, pp 346-365

Smith RH, Shore RF (2015) Environmnetal impacts of rodenticides. In: Buckle AP, Smith RH (eds) Rodent pests and their Control, 2nd edition. CAB International, Wallingford, pp 330-345

Spurr EB, Drew KW (1999) Invertebrates feeding on baits used for vertebrate pest control in New Zealand. N Z J Ecol 23:167-173

Spurr EB, Maitland MJ, Taylor GE, Wright GRG, Radford CD, Brown LE (2005) Residues of brodifacoum and other anticoagulant pesticides in target and non-target species, Nelson Lakes National Park, New Zealand. New Zealand Journal of Zoology 32 (4):237-249

Sterner RT, Goldade DA, Mauldin RE (1998) Zinc phosphide residues in gray-tailed voles (Microtus canicaudus) fed fixed particles of a $2 \%$ grain bait. Int Biodeterior Biodegrad 42 (2-3):109-113 
Thomas PJ, Mineau P, Shore RF, Champoux L, Martin PA, Wilson LK, Fitzgerald G, Elliott JE (2011) Second generation anticoagulant rodenticides in predatory birds:

Probabilistic characterisation of toxic liver concentrations and implications for predatory bird populations in Canada. Environment International 37 (5):914-920 and corrigendum 940 236. doi:10.1016/j.envint.2011.03.010

Tobin ME, Sugihara RT, Koehler AE (1997) Bait placement and acceptance by rats in macadamia orchards. Crop Prot 16 (6):507-510. doi:10.1016/s0261-2194(97)00035-5

Tosh DG, McDonald RA, Bearhop S, Llewellyn NR, Montgomery WI, Shore RF (2012) Rodenticide exposure in wood mouse and house mouse populations on farms and potential secondary risk to predators. Ecotoxicology 21 (5):1325-1332. doi:10.1007/s10646-012-0886-3

Tosh DG, Shore RF, Jess S, Withers A, Bearhop S, Montgomery WI, McDonald RA (2011) User behaviour, best practice and the risks of non-target exposure associated with anticoagulant rodenticide use. Journal of Environmental Management 92 (6):15031508. doi:10.1016/j.jenvman.2010.12.014

Towns DR, Broome KG (2003) From small Maria to massive Campbell: forty years of rat eradications from New Zealand islands. New Zealand Journal of Zoology 30 (4):377398

Townsend MG, Entwisle P, Hart ADM (1995) Use of two halogenated biphenyls as indicators of nontarget exposure during rodenticide treatments. Bull Environ Contam Toxicol 54 (4):526-533

van den Brink NW, Arblaster JA, Bowman SR, Conder JM, Elliott JE, Johnson MS, Muir DCG, Natal-da-Luz T, Rattner BA, Sample BE, Shore RF (2016) Use of terrestrial field studies in the derivation of bioaccumulation potential of chemicals. Integrated Environmental Assessment and Management 12 (1):135-145. doi:10.1002/ieam.1717

Vandenbroucke V, Bousquet-Melou A, De Backer P, Croubels S (2008) Pharmacokinetics of eight anticoagulant rodenticides in mice after single oral administration. Journal of Veterinary Pharmacology and Therapeutics 31 (5):437-445. doi:10.1111/j.13652885.2008.00979.x

Vein J, Grandemange A, Cosson JF, Benoit E, Berny PJ (2011) Are water vole resistant to anticoagulant rodenticides following field treatments? Ecotoxicology 20 (6):14321441. doi:10.1007/s10646-011-0700-7

Vyas NB, Rattner BA (2012) Critique on the Use of the Standardized Avian Acute Oral Toxicity Test for First Generation Anticoagulant Rodenticides. Hum Ecol Risk Assess 18 (5):1069-1077. doi:10.1080/10807039.2012.707934

Walker LA, Bailey LJ, Shore RF (2002) The importance of the gut and its contents in prey as a source of cadmium to predators. Environ Toxicol Chem 21 (1):76-80

Walker LA, Shore RF, Turk A, Pereira MG, Best J (2008) The Predatory Bird Monitoring Scheme: Identifying chemical risks to top predators in Britain. Ambio 37 (6):466-471

Wanless RM, Cooper J, Slabber MJ, Ryan PG (2010) Risk assessment of birds foraging terrestrially at Marion and Gough Islands to primary and secondary poisoning by rodenticides. Wildlife Research 37 (6):524-530. doi:10.1071/wr10005

WHO (1995) Environmental Health Criteria 175: Anticoagulant Rodenticides. International Programme on Chemical Safety Environmental Health Criteria. WHO, Geneva

Winters AM, Rumbeiha WK, Winterstein SR, Fine AE, Munkhtsog B, Hickling GJ (2010) Residues in Brandt's voles (Microtus brandti) exposed to bromadiolone-impregnated baits in Mongolia. Ecotoxicol Environ Saf 73 (5):1071-1077. doi:10.1016/j.ecoenv.2010.02.021 
Witmer GW, Moulton RS, Baldwin RA (2014) An efficacy test of cholecalciferol plus diphacinone rodenticide baits for California voles (Microtus californicus Peale) to replace ineffective chlorophacinone baits. International Journal of Pest Management 60 (4):275-278. doi:10.1080/09670874.2014.969361

Wolton RJ, Flowerdew JR (1985) Spatial distribution and movements of wood mice, yellownecked mice and bank voles. Symp Zoo Soc Lond 55:249-275

Wood BJ, Singleton GR (2015) Rodents in agriculture and forestry. In: Buckle AP, Smith RH (eds) Rodent pests and their Control, 2nd edition. CAB International, Wallingford, pp 33-80

Wood DA, Phillipson J (1977) The utilisation of poison hoppers designed for grey squirrel (Sciurus carolinensis) control. Biol Conserv 11:119-127 